Educational Research for Social Change (ERSC)

Volume 9 No. 1, June 2020

pp. 40-57

ersc.nmmu.ac.za

ISSN: 2221-4070

\title{
"Sausage Factory, in and out": Lecturers' Experiences of Assessing in an Era of Massification in a Teacher Education Institution ${ }^{8}$
}

\author{
Vusi Msiza \\ University of KwaZulu-Natal \\ msizav@ukzn.ac.za \\ Busisiwe Ndhlovu \\ University of Mpumalanga \\ Busisiwe.ndhlovu@ump.ac.za
}

\author{
Nthabiseng Raseroka \\ University of KwaZulu-Natal \\ Nthabz.raseroka@gmail.com
}

\section{Abstract}

The massification of higher education in South Africa has been a social justice goal and a significant milestone, given the history of the country. Massification, though, has brought challenges to the higher education sector, one of them being increasing class sizes. In this paper, we explore the experiences of lecturers in conducting assessment in a teacher education institution. We used a case study methodology, and conversations as a method of generating data - with purposive selection of five lecturers from various disciplines as the sample. For the theoretical framework, we drew on the work of two scholars: Kolb (1984) on experiential learning and Pinar's (2004) method of currere. We found that the lecturers understood the purpose of mass higher education, however, the large class sizes have influenced their assessment practices. Beyond the challenges of massification, lecturers invoked their experiences to reflect, learn, and imagine possibilities. There are possibilities for teacher education institutions to enact sustainable assessment and to navigate massification. There is also a need for further research, particularly in teacher education institutions, to theorise large classes in relation to various aspects of teacher education programmes.

Keywords: Massification, assessment, large classes, teacher education

Copyright: @ 2020 Msiza, Ndhlovu \& Raseroka

This is an open access article distributed under the terms of the Creative Commons Attribution NonCommercial License, which permits unrestricted non-commercial use, distribution, and reproduction in any medium, provided the original author and source are credited.

Please reference as: Msiza, V., Ndhlovu, B. \& Raseroka, N. (2020). "Sausage Factory, in and out": Lecturers' Experiences of Assessing in an Era of Massification in a Teacher Education Institution. Educational Research for Social Change, 9(0), 45-57. http://dx.doi.org/10.17159/2221$\underline{\text { 4070/2020/v7i0a3 }}$

\footnotetext{
${ }^{8}$ Ethical clearance number: HSS/0727/016
} 


\section{Introduction}

The South African higher education institutions (HEIs) were built to accommodate limited numbers of students with limited resources, particularly the historically, formerly black universities. Since the early 1990s, South African HEls have experienced the massification of higher education with more people gaining access to institutions of higher learning. In the many waves of change in higher education (for example, the 2015/2016 students' protests), students have demanded access to education and free education (Murris, 2016). According to Habib (2019), the higher education system had approximately 420,000 students in 1994 and grew to 1.1 million in 2014. These latter students were predominantly from groups who had been marginalised during apartheid; mass higher education for South Africa had become a moral imperative (Allais, 2014; Luckett \& Sutherland, 2000; Shoba et al., 2015).

Massification in South Africa remains a concern in myriad ways (we expand on these later in the paper). The work of Hornsby et al. (2013) broadened our theoretical understanding of the exponential growth in class sizes and, within these debates, we explore lecturers' experiences of conducting assessment in large classrooms. Our paper focuses on lecturers in a higher education teacher education institution (often referred to as teacher educators). Teacher educators are responsible for training student teachers to become qualified teachers working in basic education. We focus on how student teachers in large classes are assessed because they (unlike other students) will be assessing learners in their careers and will need to learn effective ways of doing that. We seek to demonstrate the implications of teacher educators' experiences of the quality of sustainable assessment in such contexts. Boud and Soler (2016) noted that sustainable assessment aims to ensure that students meet their present needs while being prepared for their future roles. Missing from the debates is the foregrounding of teacher education lecturers' experiences in navigating assessment during a time of massification. In essence, our study asks how lecturers ensure sustainable assessment while coping with the anxiety that results from teaching and assessing large class sizes. Our paper has the following two research questions: 1) "What are the lecturers' experiences of conducting assessment in a teacher education institution at a time of mass higher education?" and 2) "What are the implications of their experiences for the quality of sustainable assessment at a teacher education institution?"

\section{Mapping Massification and Assessment}

Internationally, particularly in the United States of America (US) and Europe after the Second World War, higher education massified to expand and provide access to knowledge (Trow, 2000). At the centre of massification is a social justice agenda that seeks to deconstruct the notion of higher education as a reserve for the elite (Mohamedbhai, 2014). As higher education classrooms have expanded in size, they have become complex and large organisations (Scott, 1995). In South Africa, the increase is more complex, given a system historically fragmented by race and class categories. The post-1994 government inherited from the apartheid era, a higher education system (Jansen, 2003) divided into the following: historically black universities (for those who were disadvantaged), historically white universities (for those who were privileged), technikons (now universities of technology), and colleges (see Akoojee \& Nkomo, 2007; Council on Higher Education, 2016).

Laudable as the pursuit of social justice and access to knowledge for all is, the nationally rapid increase in size has affected the day-to-day running of the institutions (Mohamedbhai, 2014). Mass higher education manifests differently in the 26 South African universities. Social contexts and the financial standing of the universities are some of the determinants that shape the nature of institutional massification (Hornsby \& Osman, 2014; Mohamedbhai, 2014). Institutions such as the University of KwaZulu-Natal, according to their strategic plan, are deliberately diversifying their student body by, for example, targeting students from Quintiles 1-3 schools (University of KwaZulu-Natal, 2017). 
Along with the growth of universities and the agenda of massification to create access, institutions are expected to accommodate all these students with limited resources of, for example, teaching staff, libraries, and student housing (Hornsby \& Osman, 2014). Put succinctly, Snowball $(2014$, p. 823) stated that "in many universities class sizes have increased more quickly than teaching and learning resources." We have created a paradox in which the social justice agenda is undermined by insufficient efforts to respond to the numbers. This is particularly important for teacher educators. Creating physical access for students to enter institutions without providing sufficient support hinders epistemological access and the development of specific skills that a student teacher is expected to have, according to Jansen (2008). We risk producing teachers and other graduates who are not lifelong learners and who do not have the potential to contribute to the economic and social development of the society (Hornsby et al., 2013). There is insufficient exposure to knowledge and to the disciplinespecific skills for student teachers because of large classes and shrinking funding and subsidies (Habib, 2019; Wangenge-Ouma \& Cloete, 2008). In the early 21st century, there were challenges with funding in almost all African higher education systems (Teferra \& Altbachl, 2004). And academics remain faced with "how to maintain the quality of assessment and feedback in large groups" (Ballantyne et al., 2002, p. 428).

Inherent in the debates around massification, is a focus on the implications of large classrooms that are determined by different factors; for example, class sizes vary according to schools or faculties (Hornsby \& Osman, 2014). In this study, the focus is on education. As Maringe and Sing (2014) argued, there is no universally accepted definition of what a large class is although, typically, 100 students is commonly rated a large class. However, Arvanitakis (2014) and Shoba et al. (2015) revealed that, in certain contexts, a large classroom for higher education institutions could be as many as 1,500 students. For teacher educations institutions, the issue is not so much the number of students as other aspects. As Maringe and Sing (2014) stated, it is the complexities taking place in a large classroom that are a concern for academics. These complexities relate to ensuring equality amongst the diversity of students and, of course, ensuring quality in our offerings as teacher education institutions (Maringe \& Sing, 2014). One way to intervene in a rapid growth of student enrolments is to redesign how we deliver or conduct our large classes (Cuseo, 2007).

Hornsby et al. (2013) suggested that it is possible to maintain quality in large classes. They argued that appropriate objectives and rich educational experiences should take priority over the concern of class sizes (Hornsby \& Osman, 2014). In the midst of this wave of change, there is contestation over large class teaching and assessment. In teacher education institutions, the rich educational experiences that student teachers need to improve their skills and assessment knowledge should include the effective use of assessment-for-learning and its subset, assessment-as-learning or peer assessment (Earl, 2013). In peer assessment, teacher educators create an opportunity for student teachers to conduct assessments while learning both content and skills (Falchikov, 2005).

Assessment and feedback should be frequent in order to achieve consistent learning (Boud, 2000; Cuseo, 2007). In addition to Hornsby et al.'s (2013) suggestion that academics should not exaggerate the negative implications for quality in large classes, is Cuseo's (2007) revelation that frequently, assessment in large classes comes with challenges such as delayed feedback and reduced student learning opportunities. The practices of assessment in education are predominantly summative and the use of formative assessments is declining (Boud, 2000). Institutions have resorted to information communication technology (ICT) and resources such as automated multiple choice questions (MCQs) to administer assessments (Snowball, 2014). A challenge that comes with ICT tools as a solution to large classes is the diversity of students in each institution. Massification brings student diversity in terms of language, socioeconomic background, learning styles, gender, and context (Mohamedbhai, 2014; Snowball \& Boughey, 2012). Some students from economically challenged contexts are not familiar with technological devices. For example, when we were advising students during registration, 
we realised that many were using a computer for the first time. Therefore, conducting assessments using ICT resources might require more staff to assist students, and a dedicated computer literacy course for the students. However, this is not possible without funding in a context in which, as Wangenge-Ouma and Cloete (2008) demonstrated, funding is declining. Dumping technology on students in the name of creating access to education is not the answer (Allais, 2014).

\section{Theoretical Perspectives}

We draw on Kolb and Kolb (2005) and on Kolb's (1984) experiential learning theory to demonstrate how lecturers are learning from their experience to understand massification and to enact sustainable assessment essential for teacher education. Kolb (1984) stated that for learning to occur, individuals need to recall and reflect on their past experiences. In this study, we explore the experiences of lecturers regarding assessment at a time of massification. Learning from their past experiences can enable lecturers to design assessment practices to promote lifelong learning (Lindén et al., 2013). We also draw from the work of curriculum theorist, William Pinar. We argue that to ensure sustainable assessment and to produce teachers who are lifelong learners, we ought to privilege individual experiences regarding the impact of mass higher education. In addition to Kolb, Pinar's (2004) work helped us to understand individual lecturers' reflections on their past, present, and future experiences as well as the possibilities they identify when attempting to respond to the cohorts in mass higher education. These cohorts are diverse in terms of socioeconomic background, gender, sexuality, race, and ethnicity. Lecturers need to engage in conversations to reflect on themselves and on assessment practices for teacher education institutions (Pinar, 2004). We have noted that some faculties are resorting to standardised, electronic type of assessment such as MCQs, and Pinar (2004) has critiqued this approach as an anti-intellectual project that reduces academics to mere technicians. Consequently, teacher education institutions suffer more scars as we produce teachers who are unable to enact the intellectual, scholarly conversations that underpin lifelong learning.

\section{Methodology}

The paper used a qualitative case study methodology in which the case was an institution of teacher education (Yin, 2016). We adopted a qualitative approach because we are researching lecturers' lived experiences that are distinct to their context and interpretations (Creswell, 2013). While the overall methodology for the paper is a case study, we deliberately chose a method commonly used in both narrative inquiry and life history methodologies (Clandinin \& Connelly, 2000; Goodson \& Sikes, 2001). Instead of using the usual structured, unstructured, or semi-structured interviews (see Cohen et al., 2011), we used conversations as a method to generate data. Conversations follow a similar approach to semi-structured interviews; we designed prompts to start the conversations with the participants. Through the conversations, we were able to speak to participants in a relaxed, nonintimidating manner, ensuring that participants did not feel they were being interrogated. We wanted to ensure equality between the interviewer and the participants; conversations entail listening and probing established on the basis of mutual trust (Clandinin \& Connelly, 2000). Conversations were an appropriate method to use for a topic of this nature because there are frustrations with regard to mass higher education. Therefore, the participants were free to speak and share their experiences in relation to massification and assessment. Conversations allowed them to share their experiences in a storied way, enabling them to be free while also providing in-depth data (Clandinin \& Connelly, 2000). As Eisner (1997) put it, as researchers we select a method of generating data that can elicit rich data; this method was appropriate for our purpose. Through conversations, participants were able to revisit their past experiences and to imagine their future in the academy. We purposefully recruited and selected five participants from various disciplines who are lecturers; one of the authors conducted the interviews. The lecturers were all black Africans: three men and two women. Their experience in higher education is between 11 and 25 years. 
In conducting the study, we followed all ethical procedures. The paper is drawn from a wider study that focused on lecturers' experiences of assessment in higher education and we therefore followed all ethical procedures by obtaining gatekeeper permission from the registrar's office and ethical clearance from the ethics committee. We practised voluntary participation and explained that those who wished to withdraw might do so (Flick, 2007). Given our responsibility to conduct ethical research (Cohen et al., 2011), we sought permission via an informed consent letter to audio record the conversation. The audio-recorded clips were transcribed and shared with the participants for member checking purposes. We, the three authors, read the paper to ensure rigour. All these were efforts to enhance the trustworthiness. Where there was a need to refer to the participants, we used pseudonyms to protect their identities. The data was analysed using the guidance provided by Braun et al. (2015) and Clarke and Braun's (2013) method of thematic analysis. We first read the transcripts and created codes; from the codes, we moved to formulate themes. The second level of analysis that we used was to request each author to go through the process and raise concerns where applicable. All the concerns were addressed. In the next section, the data is presented thematically.

\section{Findings}

From the data that was analysed, we generated three themes related to the focus of the paper. Theme 1 was understanding massification, Theme 2 , the challenges of massification for teaching and assessment and, Theme 3, the possibilities beyond massification. In the conversations with the participants we wanted, first, to capture their understanding of massification; then, to understand the challenges the participants have experienced or observed as a result of massification, in particular, those related to teaching and assessment. Maringe and Sing (2014) stated that mass higher education is here to stay and, according to our observations, there are merits to this statement given that student enrolments continue to grow. Therefore, we also wanted to understand the possibilities beyond massification and its challenges.

\section{Understanding Massification}

The responses of the participants, as set out in the excerpts below, indicate that they all relate massification to increasing student enrolments or class sizes. For both Richard and Lebo, massification was a new experience. For instance, Richard, who teaches in the area of science, showed uncertainty regarding the concept.

Richard: The word is not that familiar with me because I'm in science. But when I look at it, I think it is teaching a lot of people at a time without looking at the quality of teaching.

This suggests that he sees large numbers as a foreign phenomenon in the science discipline; historically, science classrooms were relatively small in both high schools and higher education institutions. Government continues to encourage young people to take up science by providing the Funza Lushaka bursaries that prioritise the sciences in education. Richard appeared to be resistant to large classes. This suggests that he is resisting the wave of change taking place in higher education, and delays acquiring new experiences. Maringe and Sing (2014) argued that the issue of quality is debatable-like beauty, quality lies in the eyes of the beholder. Richard was particularly concerned about quality, specifically the quality of teaching in large classes. The topic of quality is important in the business of producing student teachers who will, one day, become professional teachers and teach thousands of learners in South Africa. This brings us to Lebo's sentiments - that massification feels like being pressured to produce a high number of teachers in a short period of time.

Lebo: It sounds like producing a large number of teachers in a short space of time, like a sausage factory. In, out, in, out. You just need a large number. 
Lebo equated massification to the mass production of sausages in a factory. Essentially, assessment is used for certification purposes for students who go through mass production. Like sausages, students are turned into consumers and cash cows - sources of income at a time of budget cut (Maringe \& Sing, 2014). Although the point is implied, Lebo, too, was concerned about quality.

Victor: When we speak of massification of education, we are going into the economics of education. With South Africa as an example, during the apartheid era, not everyone had access to higher education. Looking at the present day society where technology is the order of the day, there is a higher number of people accessing higher education, including distance learning. One of the things that enables the ideology of massification of education is access to education.

Victor's understanding of massification sets out the core purpose of mass higher education: creating or providing access to education and knowledge to those who were previously disadvantaged, such as black South Africans during apartheid. This is in line with Scott $(1995$, p. 9), who stated that the "transition from the elite to mass higher education cannot be understood simply in terms of ... the expansion of student numbers only." At the centre of this, as indicated earlier, is the provision of access to knowledge. Victor stretched our perspective of mass higher education by highlighting massification in institutions that offer basic long-distance learning and how innovation and technology have made it possible. Snowball (2014) saw online learning management systems such as Moodle (modular objectoriented dynamic learning environment) as interactive and increasing students' engagement. As argued earlier in the paper, the successful use of online tools is dependent on the ability to address the diversity of students and on sufficient resources. We do see the possibilities of this platform for distance learning or a blended learning approach. Victor's observation of the current state of higher education, specifically in the institution where he is located, suggested the possibilities of using ICT to provide more access to knowledge. The lived experiences of these lecturers in a teacher education institution addressed the past, present, and anticipations for future possibilities in teacher education institutions (Pinar, 2004).

\section{Challenges of Massification for Teaching and Assessment}

The central concerns of the participants were intricately linked to their understanding of massification, in particular, the rapid growth of class sizes. This part of the analysis presents the challenges of massification in relation to both teaching and assessment. We reiterate that the focus of the paper is on massification and assessment, therefore, teaching cannot be left out given that it goes together with assessment. All participants linked large classes to issues of assessment.

Vicky: We do fewer assessments now, because you can't do all the assessments you used to do before massification. In my module, I used to do the history of the microscope and practicals, and it was wonderful, but we no longer do this. Now we have to leave out the skills that are needed by the students because there is not sufficient time; we have more groups to teach. I have tried to get a tutor but one of the things we have to be conscious of is that people won't do things and ensure the quality I want; this has created regular checking and moderation.

Vicky has reduced the number of assessment activities from those she used before large classes. If we consider that mass higher education in South Africa started in the 1990s, thus, within the past 30 years (Jansen, 2003), we can only imagine the state of mass higher education in South Africa in 2030 when the National Development Plan envisages that one in six people in South Africa will have a university degree (National planning commission, 2012). Frequent assessment and feedback are significant for consistent, deep learning (Cuseo, 2007) and reducing the number of assessment activities has an 
impact on student teachers who are not sufficiently engaging with the SKAV (skills, knowledges, attitudes, and values) required of a professional teacher.

Lebo provided a robust account of her observations and thoughts.

It has affected me greatly because there's no time to focus on individuals. I'm teaching so many other modules, I see the challenges. I can see that they are struggling with the content but I can only do so much. Uhm, I can't be there in every tutorial. I have to let the tutors assist them. But I still feel like the tutors are not at the level I want them to be. Besides, they are employed on temporary basis. The tutors are not the same in the following year, usually I get new ones that I need to train.... I mean students come with a lot of gaps from high school and it's difficult to identify and address them to my satisfaction because they are so many and they are going to be teachers. So we are half cooking and that's why to me massification means just making sausages. Honestly, and I'm not happy. I think I love my subject and I love teaching my subject, but it depresses me at times. I don't feel good even when I go to teaching practice and I watch them and I think, this is my product. I think assessment becomes watered down.

Lebo felt massification has caused the academy to produce half-baked professional teachers. A study by Petersen (2017) found that novice teachers in South Africa who had recently graduated felt underprepared in their teacher education programmes. The "mass production of teachers" without equipping them with sufficient pedagogical and assessment skills, makes the transition a nightmare. The idea of a factory resonates with Pinar (2004) when he argued that institutions are turned into factories of skills and knowledge. Nonetheless, there is hope for South Africa where massification is still in its infancy, provided care is exercised to avoid corporatisation (Hornsby \& Osman, 2014). Lebo referred to other lived experiences, such as assessing teaching practicum. According to her, mass higher education, in particular large classes, has watered down assessment practices. An opinion piece in the City Press newspaper by Dikotla (2019) critiqued the transfer of teacher education to universities. He called for teacher colleges to be reinstated in order to maintain the quality of didactics. We may not agree with Dikotla on reinstating the colleges (and this requires a different platform) but Dikotla's argument, and that of Lebo, suggests a widespread concern regarding teacher education institutions and the student teachers we produce. A similar concern was raised by Bertram (2003) in a study that focused on the expansion of the Bachelor of Education honours degree at the former University of Natal. Bertram found that with mass higher education, especially in teacher education, there are challenges with balancing theory and practice when teaching students.

All our participants indicated that they struggled to attend to the individual student in their respective classrooms. In large classes, lecturers do not have sufficient opportunity to focus on all the students (Arvanitakis, 2014). Lebo, above, stated that students come with knowledge (theoretical or methodological) gaps from high school. As a lecturer in a university, she felt there is insufficient attention for every student with challenges. But Richard was adamant that teaching, as opposed to a lecture method, is needed to accommodate the diversity of students.

Maybe in future, two lecturers should take the module or split the class. The lecturerstudent ratio is large, and I think we are teaching at the university and no longer lecturing because the students are from previously disadvantaged backgrounds. If you lecture them, you find that they might not perform well. Good teaching is hampered by the large number of students in the classroom. Sometimes you want to ask questions but no one will answer because some of them are shy as they are in a large classroom. So, if the university can 
reduce the numbers in the classroom and get more lecturers, it might reduce the work load and improve classroom experience.

This view requires lecturers to rethink their pedagogical and assessment practices to respond to large classes and the student of the 21st century. In this conversation, lecturers reflected on the current conditions brought by mass higher education, how higher education was before massification, and the future possibilities (Pinar, 2004).

Victor: The issue of large numbers has always been the case. Like I stated, if we look at it from the economic point of view, such as capitalism, those who have power admit more students without having to look at the available resources to meet the students' needs. Classrooms are built to accommodate a maximum of 40-50 students but looking at the large number of students coming to class, the reality of maintaining 40 in a classroom has already been defeated. How many learners are paying attention in classroom activity? The possibility of collaborative learning with a large number of students is not ideal. The lecturers' teaching and assessment strategies are affected.

Victor's frustration stemmed from not being able to use a variety of teaching and assessment methods, such as collaborative learning, due to class size. This defeats the excitement and the enthusiasm that comes with teaching in higher education. In addition, it defeats the intention of privileging formative assessment as a vehicle for lifelong learning and producing teachers who can assess sustainably (Boud, 2000). Currently, the system warrants the use of summative forms of assessment such as MCQs that are predominantly concerned with numbers and throughput. Quantifying assessment and paying attention to numbers gives little indication of the quality of learning and of teachers that teacher education institutions are producing (Biggs, 2012).

Victor reminds us of the historical context, the original capacity of the physical class sizes. He stated that physical structures were built to accommodate a number that has since doubled during massification. He felt that those who are in position of power ought to address the shortage of resources, including human resources. Allais $(2014$, p. 33) cautioned that "massification without a concomitant increase in lecturer numbers may well undermine what makes our enterprise valuable in the first place. If we cannot afford this as a society, then we cannot afford to massify higher education." We found that managing large classes required Vicky and Lebo to seek assistance from tutors to facilitate learning in tutorial groups - a view that is shared by Richard. Two challenges similar to Bertram's (2003) findings emerged. Vicky carries the burden of consistently moderating the work of the tutors in order to maintain quality. Lebo has to train new tutors every year because they are employed on contractual basis. Moreover, she shared the same sentiments that, even after training, the tutors are not at the intellectual level she expects. As a result, tenured academics end up performing managerial and administrative tasks instead of doing their research and developing staff (Bertram, 2003). Yet, providing tutors to assist lecturers in teaching and assessing large classes is a cost-effective measure.

South African universities are largely dependent on subsidies and state funding, therefore, the decline of this source of income has pushed institutions to adopt cost-effective measures (Wangenge-Ouma $\&$ Cloete, 2008). One of these is to outsource using the least experienced tutors, often postgraduate students, who require training every year. A report by the Council on Higher Education (2016) indicated that current academic staff are over extended as a result of the high number of students and the need to replace ageing with young academics. Recruiting young academics is an investment in the future of higher education, nevertheless, for under-staffed academics, mentoring these colleagues is an extra burden (Mohamedbhai, 2014). Yet, "almost everywhere there is an increasing use of part-time, casual academic labour without job security as a way of dealing with declining resources and rapid 
unpredictable change" (Trow, 2000, p. 33). Linked to the point we made earlier of imagining South African mass higher education 30 years from now, it appears that we ought to learn from other countries' experiences of massification. Indeed, according to Kolb (1984, p. 42), once individuals learn about other people's experiences "something must be done with it." Therefore, Pinar's (2004) framing assists us in the academy to look into our current experiences and envision future possibilities.

\section{Possibilities Beyond Massification}

Seeing the indications that massification will continue to exist along with the continued growth of student enrolments, we also explored possibilities beyond massification-possibilities that participants create for themselves, through experiential learning in particular, how they envision assessment in a teacher education institution. Vukile, in the excerpt below, saw the use of ICT as important to address mass higher education, but, as discussed earlier in the paper, online assessment cannot be used as a blanket approach for all lecturers.

Vukile: We created an online assessment that can cover up to one million students. We have online assessment tools, open book assessments which are related to the articles we provide and discuss online. This gives students a chance to read and be ready for assessment tasks.

Disciplinary requirements may well conflict with Vukile's view. A lecturer in early childhood education or in the philosophy of education may assert that online assessments (predominantly MCQs) are not the best way to assess knowledge in those specific disciplines. Massification has brought a diversity of students from varied socioeconomic backgrounds - some with computer illiteracy-and, based on our evidence, institutions of higher education have not responded comprehensively to matters of inclusivity. The provision of resources to compensate for or accommodate the rapid growth of mass higher education is moving at a snail's pace, deepening the access/success debate (Jansen, 2008). The issue of resources vis-à-vis the increasing number of enrolments is also concerning at the University of Zambia; for example, Kanyengo (2009) found that enrolments have increased but the library resources remained the same as when it was established in 1966. In South Africa, progress could be moving too slowly, as argued by Jansen, but in other contexts such as Zambia, there hasn't been any significant response to massification. When asked to consider what would help them in dealing with the challenges, Lebo replied,

I can't think of anything, because I don't believe that a machine is good enough for teacher trainees. So I think that you need more manpower than more machines or changing strategies to suit marking with a machine. Maybe if I have a large class, it should be the only class that I teach. I shouldn't have another large class. In this way, I can focus and have more strategies to see them individually over this time, maybe assess them in groups. Then I would have time to focus on doing good job with one module.

In the excerpt above, Lebo rejected the use of technology for marking-such as the automated MCQs that mark and provide feedback instantly. Reflecting on the current challenges, she believed that human resources in the form of lecturers are more important for conducting assessments because they are able to observe social aspects and constantly change the assessment strategy. Technology cannot replace the nuances of human beings who make our teacher education classes exciting and inspiring for the student teachers (Arvanitakis, 2014). A study conducted by Rhodes University's economics department found that the students appreciated blended learning and thought it enhanced teaching and learning in large class sizes (Snowball, 2014). Teacher education institutions consist of content modules such as mathematics, geography, and English followed by methodology modules 
focusing on different ways to teach the content. They should therefore consider which of the two, content or methodology, can be offered through blended approaches.

According to Pinar (2004), lecturers should constantly ask themselves the meaning of the present moment-in this case mass higher education. Lebo, having analysed the present moment, believed that to overcome massification and the assessment deficits that are brought by large classes, it is better to focus only on one module and one class. The challenge with that proposal would be in the assessment; one lecturer cannot process all the assessments, while outsourcing the task without proper training might cause dissatisfaction for students or the lecturer. It is, though, impressive that lecturers are creating ways to alleviate the situation they face. Kolb and Kolb (2005) maintained that such a process is important, particularly to engage with our experiences and relearn from them. In a study by Arvanitakis (2014), the author reflected on a conversation with a student in which the student said he was an "academic pirate" and "pirates are resourceful they learnt to use their environment." (p. 744). This is another focus for academics in teacher education, especially noting limited research on teacher education and massification-to dance in the wave of change in order to respond to challenges of large classes while also producing teachers who are lifelong learners and able to function globally.

\section{Discussion and Conclusion}

In this paper, we explored the experiences of lecturers conducting assessments in a time of massification. We specifically focused on lecturers in a teacher education institution. The findings showed different conceptions of massification. The participating lecturers conceptualised it both as a social justice project and as a project that has brought significant challenges for assessment. Conducting assessment in a sustainable way, as argued by Boud (2000), carries more significance for the work that is done in a teacher education institution (this does not suggest we undermine other sectors). Producing professional teachers who are lifelong learners, whose assessment practices are based on knowledge, skills, and different ways of thinking, requires the transformation of teaching and learning in South Africa. Teacher education institutions should avoid falling into the trap of using assessment for certification and accountability purposes. Instead, we ought to reposition assessment as a meaningful contributor to teaching and learning (Boud \& Soler, 2016; Earl, 2006; Pinar, 2004). Our findings demonstrated that, beyond the challenges brought by massification, which include the diversity of students and large classes, lecturers are hopeful and determined to participate in the wave of change by reflecting on their experiences, interrogating themselves, and relearning (Kolb et al., 2001; Pinar, 2004). It is unfortunate that the existing wave of change caused by the COVID-19 pandemic has affected all higher education institutions, globally, and more deeply in the Global South. Our institutions, with large numbers and few resources, are left to ponder how to navigate teaching large classes remotely with a population of students from diverse socioeconomic backgrounds. The danger here is that mass assessment strategies may offer an easy way out.

One participant argued for teaching as opposed to using a lecture method in our classes. We think the point is important because it calls on lecturers to engage in what Pinar (2004) called complicated conversations in order to reflect on the relevance of the methods that are used. These include, for example, the use of a lecture method and traditional forms of assessment such as academic essays. Biggs (2014) emphasised that, when conducting assessment, there should be a constructive alignment between the objectives and the type of assessments that are given to students. Also, in large classes, there is a need for lecturers to create opportunities for student teachers to practice assessment skills, for example, peer or self-assessment that will be needed when they become teachers (Boud, 2000; Falchikov, 2005). Therefore, the participants' experiences of massification should be geared towards strengthening the quality of assessment and of teaching. 
ICT methods of teaching and assessment are already advocated for use in higher education but, in doing so, we need to be cautious not to adopt simplistic methods. For example, when using an eassessment method for approximately 1,500 students, anecdotally, we have observed cyber cheating; students snapshot their screens and share amongst themselves. This is possible because there is a lack of resources to accommodate all the students to write at the same time. Instead of a total rejection of manual ways of doing assessments over ICT, other scholars have argued for a blended approach (see Hornsby \& Osman, 2014). Another important aspect in higher education is to work and engage the students in order to embed ourselves as teacher educators into their lives and encourage them to see the world differently (Arvanitakis, 2014).

Earlier in the paper, we used 30 years from now as a target to imagine the scope and nature of higher education in South Africa. Using this as a target will enable lecturers in a teacher education institution to imagine their future and the type of a student teacher they want to produce. Responding to current university challenges to address inequalities in South Africa, which, inter alia, are caused by mass higher education and insufficient student funding, Habib (2019, p. 182) stated that "universities are constrained by the Department of Basic Education's failure to provide quality education to all South Africa's children." We would rather argue that it is the quality of teachers we produce as teacher education institutions that contributes to either the success or the failure of basic education. The COVID-19 pandemic has pushed the academy to rethink teaching and assessment. And, to redefine what assessment is for a mass higher education with significant diversity of student population. Apart from the disruptions of the COVID-19 pandemic, more research is required on large classes especially in the humanities and social sciences in teacher education programmes including the Post Graduate Certificate (PGCE) that covers large numbers in selected institutions. We emphasise that to alleviate current challenges, we need to reflect on our past, on our skills, and on our knowledge, while envisaging the future.

\section{References}

Akoojee, S., \& Nkomo, M. (2007). Access and quality in South African higher education: The twin challenges of transformation. South African Journal of Higher Education, 21(3), 385-399.

Allais, S. (2014). A critical perspective on large class teaching: The political economy of massification and the sociology of knowledge. Higher Education, 67(6), 721-734.

Arvanitakis, J. (2014). Massification and the large lecture theatre: From panic to excitement. Higher Education, 67(6), 735-745.

Ballantyne, R., Hughes, K., \& Mylonas, A. (2002). Developing procedures for implementing peer assessment in large classes using an action research process. Assessment \& Evaluation in Higher Education, 27(5), 427-441.

Bertram, C. (2003). Moving towards massification: Reflections on a mixed-mode teacher education programme. Perspectives in Education, 21(2), 71-82.

Biggs, J. (2012). What the student does: Teaching for enhanced learning. Higher Education Research \& Development, 31(1), 39-55.

Biggs, J. (2014). Constructive alignment in university teaching. HERDSA Review of Higher Education, $1(1), 5-22$.

Boud, D. (2000). Sustainable assessment: Rethinking assessment for the learning society. Studies in Continuing Education, 22(2), 151-167.

Boud, D., \& Soler, R. (2016). Sustainable assessment revisited. Assessment \& Evaluation in Higher Education, 41(3), 400-413. 
Braun, V., Clarke, V., \& Terry, G. (2015). Thematic analysis. In P. Rohleder \& A. Lyons (Eds.), Qualitative research in clinical and health psychology (pp. 95-113). Palgrave Macmillan.

Clandinin, D. J., \& Connelly, F. M. (2000). Narrative inquiry: Experience and story in qualitative research. Jossey-Bass.

Clarke, V., \& Braun, V. (2013). Teaching thematic analysis: Overcoming challenges and developing strategies for effective learning. The Psychologist, 26(2), 120-123.

Cohen, L., Manion, L., \& Morrison, K. (2011). Research methods in education (7th ed.). Routledge.

Council on Higher Education. (2016). South African higher education reviewed: Two decades of democracy. Council on Higher Education.

Creswell, J. W. (2013). Qualitative inquiry \& research design (3rd ed.). SAGE.

Cuseo, J. (2007). The empirical case against large class size: Adverse effects on the teaching, learning, and retention of first-year students. The Journal of Faculty Development, 21(1), 5-21.

Dikotla, M. (2019, October 06). Bring back the teachers' colleges. City Press, p. 5.

Earl, L. (2006). Assessment: A powerful lever for learning. Brock Education: A Journal of Educational Research and Practice, 16(1), 1-15.

Earl, L. M. (2013). Assessment as learning: Using classroom assessment to maximize student learning (2nd ed.). Corwin Press.

Eisner, E. W. (1997). The promise and perils of alternative forms of data representation. Educational Researcher, 26(6), 4-10.

Falchikov, N. (2005). Improving assessment through student involvement: Practical solutions for aiding learning in higher and further education. RoutledgeFalmer.

Flick, U. (Ed.) (2007). Designing qualitative research. SAGE.

Goodson, I., \& Sikes, P. (2001). Life history research in educational settings: Learning from lives. Open University Press.

Habib, A. (2019). Rebels and rage: Reflecting on \#FeesMustFall. Jonathan Ball.

Hornsby, D., Osman, R., \& De Matos-Ala, J. (2013). Large classes, student learning and quality education. In D. Hornsby, R. Osman, \& J. De Matos-Ala (Eds.), Large-class pedagogy: Interdisciplinary perspectives for quality higher education (pp. 173-178). Sun Media Metro.

Hornsby, D. J., \& Osman, R. (2014). Massification in higher education: Large classes and student learning. Higher Education, 67(6), 711-719. doi:10.1007/s10734-014-9733-1

Jansen, J. (2003). The state of higher education in South Africa: From massification to merger. In J. Daniel, A. Habib, \& R. Southall (Eds.), State of the nation: South Africa, 2003-2004 (pp. 290-311). HSRC Press.

Jansen, J. D. (2008). Reflections on meaningful access to education. South African Child Gauge, 2009, 7-8.

Kanyengo, C. W. (2009). A library response to the massification of higher education: The case of the University of Zambia library. Higher Education Policy, 22(3), 373-387.

Kolb, A. Y., \& Kolb, D. A. (2005). Learning styles and learning spaces: Enhancing experiential learning in higher education. Academy of Management Learning \& Education, 4(2), 193-212.

Kolb, D. A. (1984). Experiential learning: Experience as the source of learning and development. Prentice Hall. 
Kolb, D. A., Boyatzis, R. E., \& Mainemelis, C. (2001). Experiential learning theory: Previous research and new directions. In R. J. Sternberg \& L.-f. Zhang (Eds.), Perspectives on thinking, learning, and cognitive styles (pp. 227-249). Routledge.

Lindén, J., Ohlin, M., \& Brodin, E. M. (2013). Mentorship, supervision and learning experience in PhD education. Studies in Higher Education, 38(5), 639-662. https://doi.org/10.1080/03075079.2011.596526

Luckett, K., \& Sutherland, L. (2000). Assessment practices that improve teaching and learning. In S. Makoni (Ed.), Improving teaching and learning in higher education : A handbookfor Southern Africa (pp. 98-130). Witwatersrand University Press/Higher Education Research Development Society of Australasia.

Maringe, F., \& Sing, N. (2014). Teaching large classes in an increasingly internationalising higher education environment: Pedagogical, quality and equity issues. Higher Education, 67(6), 761-782.

Mohamedbhai, G. (2014). Massification in higher education institutions in Africa: Causes, consequences and responses. International Journal of African Higher Education, 1(1), 59-83.

Murris, K. (2016). \#RhodesMustFall: A posthumanist orientation to decolonising higher education Institutions. South African Journal of Higher Education, 30(3), 274-294.

National Planning Commission (NPC). (2012). National development plan 2030: Our future-make it work. https://www.gov.za/sites/default/files/gcis document/201409/ndp-2030-our-futuremake-it-workr.pdf

Petersen, N. (2017). The liminality of new foundation phase teachers: Transitioning from university into the teaching profession. South African Journal of Education, 37(2), 1-9.

Pinar, W. F. (2004). What is curriculum theory? Lawrence Erlbaum.

Scott, P. (1995). The meanings of mass higher education. SRHE/Open University Press.

Shoba, M., Nzimande, N., \& Makhasane, S. D. (2015). Demystifying large classes teaching in a university: Lessons for basic education teachers. Journal of Educational Studies, (Special issue 1), 270-287.

Snowball, J. D. (2014). Using interactive content and online activities to accommodate diversity in a large first year class. Higher Education, 67(6), 823-838.

Snowball, J. D., \& Boughey, C. (2012). Understanding student performance in a large class. Innovations in Education and Teaching International, 49(2), 195-205. doi:10.1080/14703297.2012.677658

Teferra, D., \& Altbachl, P. G. (2004). African higher education: Challenges for the 21st century. Higher Education, 47(1), 21-50.

Trow, M. (2000). From mass higher education to universal access: The American advantage. Minerva, $37(4), 303-328$.

University of KwaZulu-Natal. (2017). Annual report. https://www.ukzn.ac.za/media-publicationsreports/annual-reports/

Wangenge-Ouma, G., \& Cloete, N. (2008). Financing higher education in South Africa: Public funding, non-government revenue and tuition fees. South African Journal of Higher Education, 22(4), 906919.

Yin, R. K. (2016). Qualitative research from start to finish (2nd ed.). Guilford. 